\title{
POR UM DELINEAMENTO CONCEITUAL DA COMPLEXIDADE SOCIAL: AS EXPERIÊNCIAS DO MERCOSUL E DO ORÇAMENTO PARTICIPATIVO NA ANÁLISE DE ANDRÉ- JEAN ARNAUD SOBRE A GOVERNANÇA
}

FOR A CONCEPTUAL OUTLINE OF SOCIAL COMPLEXITY: THE EXPERIENCES OF MERCOSUR AND PARTICIPATORY BUDGETING IN THE ANALYSIS OF ANDRÉ-JEAN ARNAUD ON GOVERNANCE

POR UN DELIMEAMIENTO CONCEPTUAL DE LA COMPLEJIDAD SOCIAL: LAS EXPERIENCIAS DEL MERCOSUR Y DEL PRESUPUESTO PARTICIPATIVO EN EL ANALISÍS DE ANDRÉ-JEAN ARNAUD SOBRE LA GOBERNANZA

\section{Orlando Villas Bôas Filho²}

Licença CC BY:

Artigo distribuído sob os termos Creative Commons, permite uso e distribuição irrestrita em qualquer meio desde que o autor credite a fonte original.

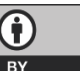

\begin{abstract}
Resumo: $O$ presente artigo pretende examinar o modo pelo qual as experiências do Mercosul e do orçamento participativo são tratadas por André-Jean Arnaud no âmbito de sua análise da governança. Para tanto, focaliza, em primeiro lugar, o delineamento conceitual dado pelo autor ao fenômeno da governança ao longo de sua obra. A partir daí, recupera as linhas gerais de sua abordagem acerca desse fenômeno em suas múltiplas formas de expressão. Em seguida, são enfocados os aspectos fundamentais de seu exame do Mercosul no âmbito da governança regional e do orçamento participativo no contexto da governança territorial. Por fim, em termos conclusivos, procura sublinhar a importância da análise de André-Jean Arnaud para a compreensão dessas duas experiências como concreções ilustrativas do fenômeno da governança.
\end{abstract}

Palavras-chave: governança, Mercosul, orçamento participativo, sociologia jurídica, democracia

\footnotetext{
$1 \quad$ Este artigo é dedicado à memória de André-Jean Arnaud por tudo o que sua obra significa para a sociologia jurídica e, em especial, para a análise relativa à questão da governança. É também um reconhecimento por sua generosa interlocução que, entre outras coisas, despertou meu interesse pelo tema.

2 Professor Doutor da Faculdade de Direito da Universidade de São Paulo e Professor Associado da Faculdade de Direito da Universidade Presbiteriana Mackenzie. Graduação e Licenciatura Plena em História pela Universidade de São Paulo. Graduação em Direito pela Pontifícia Universidade Católica de São Paulo. Graduação em Filosofia pela Universidade de São Paulo. Mestrado em Direito e Doutorado em Direito, na área de concentração Filosofia e Teoria Geral do Direito, pela Universidade de São Paulo. Pós-Doutorado na Université de Paris $X$ - Nanterre, França. Pós-Doutorado na École Normale Supérieure de Paris, França.
} 
Abstract: This paper examines the way in which the experiences of the Mercosur and of participatory budgeting are dealt with by André-Jean Arnaud in his analysis of governance. For this, it examines, firstly, the conceptual delineation given by the author to the phenomenon of governance throughout his work. It then outlines the general elements of the author's approach to this phenomenon in its multiple forms of expression. Following this analysis, it focuses on the fundamental aspects of his approach to Mercosur in the context of regional governance and participatory budgeting in the context of territorial governance. Finally, it concludes by emphasizing the importance of Andre-Jean Arnaud's analysis for our understanding of these two experiences as illustrative examples of the phenomenon of governance.

Keywords: governance, Mercosur; participatory budgeting; legal sociology; democracy.

Resumen: El presente artículo pretende examinar el modo por el cual las experiencias del Mercosur y del presupuesto participativo son tratadas por André-Jean Arnaud en el ámbito de su análisis de la gobernanza. Para tanto, enfoca, en primero lugar, el delineamiento conceptual dado por el autor al fenómeno de la gobernanza a lo largo de su obra. A partir de ahí, se recupera las líneas generales de su abordaje acerca de este fenómeno en sus múltiples formas de expresión. En seguida, son enfocados los aspectos fundamentales de su examen del Mercosur en el ámbito de la gobernanza regional y del presupuesto participativo en el contexto de la gobernanza territorial. Por fin, en términos conclusivos, se busca subrayar la importancia del análisis de André-Jean Arnaud para la comprensión de estas dos experiencias como concreciones ilustrativas del fenómeno de la gobernanza.

Palabras clave: gobernanza, Mercosur, presupuesto participativo, sociología jurídica, democracia.

\section{INTRODUÇÃO}

André-Jean Arnaud foi, seguramente, um dos juristas franceses que, entre o final do século passado e início deste, mais influenciou a discussão sociológica do direito no Brasil. $^{3}$ A versatilidade e a desenvoltura com que transitava pelos âmbitos do direito, da sociologia, da filosofia e da história desorientavam seus leitores, sobretudo os mais ávidos por enquadrar seu pensamento em algum domínio mais definido. Logo, é possível afirmar a seu respeito que se trata de um teórico inclassificável e perturbador. A erudição que lhe franqueava a passagem de um domínio do saber a outro se aliava à sua aversão às ortodoxias e aos paroquialismos acadêmicos. Arnaud possuía a capacidade de subverter, com elegância, as certezas que norteiam os olhares acomodados e as esquematizações dogmáticas que acalentam o sono dos juristas arraigados a representações defasadas e simplificadoras da regulação jurídica na sociedade hodierna. Sua obra

3 A respeito, ver: SCHWARTZ, Germano; COSTA, Renata Almeida da. André-Jean Arnaud e sua contribuição para a sociologia do direito brasileira. Revista Brasileira de Sociologia do Direito, ABraSD, v. 3, n. 3, p. 114-127, set.-dez. 2016. 
se afigura, assim, como expressão do que Jacques Commaille designa de "pesquisa de complementaridades", ${ }^{4}$ motivo pelo qual é possível afirmar que se trata, como observa François Ost, de um modelo de interdisciplinaridade. ${ }^{5}$

Cumpre ressaltar que a preocupação com a análise das mutações experimentadas pela regulação jurídica - especialmente em virtude do impacto da globalização, por ele considerada, conceitualmente, um paradigma de enorme valor heurístico para a discussão sociológica acerca do direito na atualidade $^{6}$ - sempre esteve presente na obra de André-Jean Arnaud. ${ }^{7}$ Sua postura crítica ao dogmatismo de viés monista, presente no senso comum dos juristas, expressa-se na recusa em conceber o direito como um plexo normativo emanado exclusivamente do $E_{s t a d o}^{8}$ e, consequentemente, no enfrentamento - profundo e mediante uma interlocução estruturada com autores de diversas tradições - de questões altamente intrincadas que se mostram fundamentais na sociologia jurídica hoje, tais como: o impacto da globalização na regulação jurídica; a corrosão da lógica top-down de decisão; o pluralismojurídico; as reconfigurações da "razãojurídica"; a internacionalização dos direitos humanos; a emergência de novos atores sociais, especialmente a sociedade civil, na tomada de decisões, etc.

4 Cf. COMMAILLE, Jacques. À quoi nous sert le droit pour comprendre sociologiquement les incertitudes des sociétés contemporaines? SociologieS [En ligne], Dossiers, Sociétés en mouvement, p. 9 e 12, 2016. Disponível em: <http://sociologies.revues.org/5278>. Acesso em: 7 mar. 2016.

5 Cf. OST, François. In memoriam - André-Jean Arnaud (1936-2015). Revue Interdisciplinaire d'Études Juridiques, v. 76, p. 2, 2016.

6 Cf. ARNAUD, André-Jean. Jean Carbonnier. Un juriste dans la cité. Paris: LGDJ, 2012. p. 134. Para uma análise que inscreve a perspectiva de André-Jean Arnaud no horizonte da "sociedade mundial", tal como a concebe a teoria dos sistemas de Niklas Luhmann, ver: VILLAS BÔAS FILHO, Orlando. Communication. In: ARNAUD, AndréJean (Dir.). Dictionnaire de la globalisation - droit, science politique, sciences sociales. Paris: LGDJ, 2010. p. 71; VILLAS BÔAS FILHO, Orlando. Différenciation fonctionnelle. In: ARNAUD, André-Jean (Dir.). Dictionnaire de la globalisation - droit, science politique, sciences sociales. Paris: LGDJ, 2010. p. 144.

7 É possível observar essa preocupação já nos primeiros textos do autor. A respeito, ver: ARNAUD, André-Jean. Les origines doctrinales du code civil français. Paris: LGDJ, 1969. p. 20. A respeito, ver: CAPELLER, Wanda. André-Jean Arnaud: uma obra de transgressão. In: ARNAUD, André-Jean. O direito traído pela filosofia. Tradução de Wanda de Lemos Capeller e Luciano Oliveira. Porto Alegre: Fabris, 1991. p. 7-20; ORTIZ, Laure. Préface. In: ARNAUD, André-Jean. La gouvernance. Un outil de participation. Paris: LGDJ, 2014. p. I-VIII.

8 Cf. ARNAUD, André-Jean. Entre modernité et mondialisation. Leçons d'histoire de la philosophie du droit et de l'État. 2. ed. Paris: LGDJ, 2004. p. 18; ARNAUD, André-Jean. Pour une pensée juridique européenne. Paris: PUF, 1991. p. 203 e ss.; ARNAUD, André-Jean. Du jeu fini au jeu ouvert. Réflexions additionnelles sur le Droit postmoderne. Droit et Société, n. 17-18, p. 45-47, 1991. Acerca da inscrição do pensamento de André-Jean Arnaud no debate francês sobre o pluralismo jurídico, ver: ARNAUD, André-Jean. Le droit trahi par la sociologie. Une pratique de l'histoire. Paris: LGDJ, 1998, p. 41-43; ARNAUD, André-Jean; NOREAU, Pierre. The sociology of law in France: trends and paradigms. Journal of Law and Society, v. 25, n. 2, p. 275-276, 1998; GARCÍA VILLEGAS, Mauricio; LEJEUNE, Aude. La sociologie du droit en France: de deux sociologies à la création d'un projet pluridisciplinaire. Revue Interdisciplinaire d'Études Juridiques, v. 66, n. 1, p. 23-24, 2011; GARCÍA VILLEGAS, Mauricio. Les pouvoirs du droit. Analyse comparée d'études sociopolitiques du droit. Paris: LGDJ, 2015, p. 282. 
Essas questões - cujo rol, dada a sua magnitude, não é possível capitular aqui - revelam a sua imensa contribuição ao debate histórico, filosófico e sociológico acerca do direito e permitem identificar claramente as razões que alçam sua obra ao estatuto de um clássico. ${ }^{9}$ E, especialmente no âmbito da discussão sociológica, sua preocupação com a questão da governança sempre existiu. ${ }^{10}$ Por esse motivo, seu último livro, intitulado La gouvernance. Un outil de participation, manifesta toda a coerência de uma empreitada que, no plano da abordagem sociológica do direito, afigura-se como referência incontornável a todos aqueles que pretendam compreender a complexidade assumida pela regulação jurídica atual.

O tema da governança pode ser considerado, portanto, um exemplo da potencialidade das análises de André-Jean Arnaud para a elucidação das transformações sofridas pela regulação jurídica atual. Atento a tais transformações, Arnaud procurou, especialmente em sua última obra, sublinhar a relevância da governança como fenômeno expressivo das reconfigurações importantes ocorridas no âmbito da decisão e da regulação. ${ }^{11} \mathrm{Em}$ meio a esse estudo, o autor enfoca as experiências do Mercosul e do orçamento participativo tomando-as como concreções ilustrativas da governança no plano regional e no territorial/ local, respectivamente. Assim, por um lado, sua análise tem um enorme potencial de elucidação de tais experiências, uma vez que as inscreve no horizonte de uma

$9 \quad$ A respeito, ver: CARBONNIER, Jean. Resenha crítica do livro "Essai d'analyse structurale du Code Civil français. La règle du jeu dans la paix bourgeoise". Archives de Philosophie du Droit, v. 20, p. 447-449, 1975. Para um elenco dos domínios de pesquisa da sociologia jurídica, ver: ARNAUD, André-Jean; FARIÑAS DULCE, María José. Introduction à l'analyse sociologique des systèmes juridiques. Bruxelles: Bruylant, 1998. p. 185-186.

10 A respeito, sem mencionar a obra intitulada La gouvernance. Un outil de participation, que será objeto de uma análise mais detida adiante, ver, por exemplo: ARNAUD, André-Jean. Entre modernité et mondialisation. Leçons d'histoire de la philosophie du droit et de l'État, p. 217 e ss.; ARNAUD, André-Jean. Critique de la raison juridique 2. Gouvernants sans frontières. Entre mondialisation et post-mondialisation. Paris: LGDJ, 2003. p. 330 e ss. Cumpre notar que, em um e-mail que me encaminhou em 22.04.2012, André-Jean Arnaud, ao analisar o projeto expresso em sua Critique de la raison juridique, ressaltava que "La CRJ-1 développait essentiellement un paradigme (au sens de Kuhn), celui de l'AVANT-DIRE-DROIT. La CRJ-2 a développé ce qui, dans l'avant-dire-droit concernait le rôle innovant de la société civile. A l'époque de la publication de la CRJ-1, j'évoquais surtout le rôle d'une sociologie juridique; avec mes recherches qui m'ont conduit à publier le vol 2 de la CRJ, j'ai pu développer, sur le même point, ce qui relève du paradigme de la 'gouvernance participative'. Un vol 3 de la CRJ pourrait éventuellement, si je mène mes recherches à bien, développer ce qui, dans la CRJ-1 concernait le rôle des spécialistes, observatoires, experts... Je développerais ainsi un 3e paradigme, celui d'INTELLIGENCE - ce que j'appelle la 'Policy Intelligence', intraduisible en français sinon sous l'expression, bien longue, d'Intelligence en matière de politiques publiques" (ARNAUD, André-Jean. E-mail enviado a Orlando Villas Bôas Filho em 22.04.2012. Nota-se em tal mensagem a centralidade assumida pela governança no segundo volume da Critique de la raison juridique. A respeito, ver também: CAPELLER, Wanda. André-Jean Arnaud: uma obra de transgressão, p. 15).

11 Cf. ARNAUD, André-Jean. La gouvernance. Un outil de participation. Paris: LGDJ, 2014. Para uma resenha, em português, da referida obra, ver: VILLAS BÔAS FILHO, Orlando. As transformações da regulação jurídica na sociedade contemporânea: a governança como paradigma (resenha de ARNAUD, André-Jean. La gouvernance. Un outil de participation. Paris: LGDJ, 2014). Revista Direito GV, v. 12, n. 1, p. 251-259, jan.-abr. 2016. 
nova economia regulatória, fortemente atrelada ao fenômeno da globalização, que tem sido, em termos conceituais, designada de governança. Por outro lado, ao enfocar tais experiências, permite também explicitar os arranjos concretos experimentados por abstrações conceituais tais como a governança e a globalização.

Vale notar que o objetivo deste artigo não é realizar uma revisão da extensa bibliografia existente no Brasil acerca do Mercosul e do orçamento participativo. Sua finalidade consiste apenas em explicitar a potencialidade da contribuição de André-Jean Arnaud para a compreensão desses assuntos. Conforme mencionado, trata-se de uma contribuição particularmente relevante, pois inscreve ambas as experiências no âmbito das análises dirigidas ao fenômeno da governança que, nos últimos anos, tem recebido cada vez mais atenção pela literatura jurídicosociológica, inclusive na América Latina. ${ }^{12}$ Nesse sentido, sem obviamente desconsiderar a importância dos diversos estudos que, no Brasil, enfocam as experiências do Mercosul e do orçamento participativo, este artigo irá se cingir à perspectiva de Arnaud e, a partir dela, à de seus interlocutores diretos, fazendo apenas ocasionalmente remissão a outros autores. ${ }^{13}$

Dessarte, com o intuito de examinar a abordagem realizada por AndréJean Arnaud acerca do Mercosul e do orçamento participativo no bojo de sua investigação relativa à governança, este artigo procurará empreender, inicialmente, uma breve alusão ao delineamento conceitual dado pelo autor ao fenômeno da governança ao longo de sua obra. A partir daí, serão recuperadas, em linhas gerais,

as considerações feitas por Arnaud acerca desse fenômeno em suas múltiplas

12 Tendo por horizonte as discussões ocorridas no XI Congreso Nacional y I Latinoamericano de Sociología Jurídica, realizado em outubro de 2010, Adriana Mack e Rubén Donzis, referindo-se aos conflitos "glocalizados", ressaltam que "los conflictos glocalizados, marcan una nueva frontera que se reaviva con la emergencia de reclamos por vías no convencionales, las que exponen un desapego por las estructuras clásicas de articulación y circulación de la comunicación política. [...] La pregunta que surge ante esta situación descrita es si los esquemas de gobernanza son una estrategia política que garantiza la gobernabilidad de las sociedades, mientras se mantiene la legitimidad de las instituciones a cambio de ceder autoridad política a los actores económicos y sociales. No obstante, esta alternativa despierta interrogaciones respecto de que puedan ser identificados estos procedimientos por los propios actores y la eficacia que puedan tener los esquemas de gobernanza que se pongan en procura de solucionar conflictos glocalizados" (MACK, Adriana; DONZIS, Rubén. Las consecuencias de la globalización en el campo sociojurídico. In: GONZÁLES, Manuela G.; LISTA, Carlos A. Sociología jurídica en Argentina: tendencias y perspectivas. Buenos Aires: Eudeba, 2011. p. 41-42. Grifos dos autores). A respeito, ver também: GONZÁLEZ, Felipe. Por qué pensar la gobernanza? In: GONZÁLEZ, Felipe (Coord.); DAMIANI, Gerson; FERNÁNDEZ-ALBERTOS, José (Orgs.). Governança e democracia representativa. São Paulo: Editora da Universidade de São Paulo, 2017, p. 33-54.

13 Não faria sentido capitular aqui a ampla literatura existente sobre esses dois temas no Brasil. No que concerne aos interlocutores brasileiros de Arnaud acerca do Mercosul, cumpre aludir, especialmente, aos seguintes autores: Wanda Capeller, Deisy Ventura, Roberto Falchetti, José Gabriel Assis de Almeida, Nadya Araujo Guimarães e Frederico M. Magalhães Marques. No que tange à questão do orçamento participativo, Arnaud mobiliza, especialmente, as análises de Rebecca Abers, Denis Rosenfield e Fábio Duarte. Adiante, alguns desses autores serão enfocados. 
formas de expressão. Em seguida, será enfocada sua análise do Mercosul no âmbito da governança regional e do orçamento participativo no contexto da governança territorial/local. Por fim, em termos conclusivos, procurar-se-á sublinhar a importância do estudo de André-Jean Arnaud para a compreensão dessas duas experiências como concreções ilustrativas do fenômeno da governança.

\section{A TEMÁTICA DA GOVERNANÇA NA OBRA DE ANDRÉ-JEAN ARNAUD}

A questão da governança aparece em diversos escritos de André-Jean Arnaud e ganha progressiva expressão em sua obra de contorno propriamente sociológico. Em um artigo, publicado em 1997 na revista Droit et Société, no qual o autor abordava criticamente a regulação jurídica no contexto da globalização, a governançajá era enfocada como um termo de grande adequação para a explicação do desenvolvimento de um processo interativo, dinâmico e projetivo de decisão instado a evoluir constantemente para dar respostas adequadas a circunstâncias cambiantes. Para Arnaud, o desenvolvimento desse tipo de experiência decorreria da crescente difusão de informações, saberes, recursos e capacidades a um contingente mais geral de pessoas de modo a lhes permitir o desenvolvimento de políticas e práticas, voltadas ao interesse comum, nos interstícios da intervenção estatal ou interestatal. Nesse sentido, enfatizava-se nesse artigo que, como conceito, a governança permitiria transcender a velha ideia de uma tomada de decisão soberana, de tipo top-down, emanada em nome do poder público. ${ }^{14}$

Em seguida, a questão da governança recebeu um amplo tratamento no livro Critique de la raison juridique 2. Gouvernants sans frontières. Entre mondialisation et post-mondialisation, publicado em 2003, no qual ela é enfocada sob os mais diversos ângulos. ${ }^{15}$ Nessa obra, após sublinhar a especificidade

14 Cf. ARNAUD, André-Jean. De la régulation par le droit à l'heure de la globalisation. Quelques observations critiques. Droit et Société, n. 35, p. 32-33, 1997.

15 Vale ressaltar que, também no ano de 2003, um dossiê da revista Droit et Société foi dedicado à questão da governança. Organizado por Wanda Capeller e Vincent Simoulin, o dossiê sublinha a importância da governança como matriz conceitual para o diálogo interdisciplinar. Dado o protagonismo de André-Jean Arnaud na referida revista, não seria descabido supor que ele tenha incentivado a seleção desse tema. Assim, no primeiro artigo que o compõe, Vincent Simoulin analisa a sua relevância para a questão da ação pública, na medida em que permitiria esclarecer as práticas contemporâneas direcionadas a uma coordenação alheia às hierarquias tradicionais. Em seguida, Catherine Baron examina o caráter polissêmico do conceito de governança, ressaltando, entre outras coisas, que ela expressaria uma forma de apreensão das novas práticas e representações suscitadas pela globalização. Anne Isla a discute no plano da Comunidade Europeia procurando traçar, a partir daí, as relações entre direito e economia. Finamente, no artigo que encerra o dossiê, Claude Dupuy, Isabelle Leroux e Frédéric Wallet, partindo da constatação da emergência de novas formas de territorialidade, procuram mostrar a importância 
do conceito de governança relativamente aos de governo, governabilidade e governamentalidade, André-Jean Arnaud dedicou especial ênfase à sua utilização como veículo de participação na produção da regulação jurídica atual. ${ }^{16}$ Tratase de uma abordagem de grande amplitude que, obviamente, não é passível de ser reproduzida aqui. Cumpre apenas notar que, nela, Arnaud já definia a governança como uma forma de gestão eficaz, tanto do domínio privado como do administrativo e do político, que se expressa em diversos planos: global, regional, nacional e territorial. ${ }^{17}$

A questão da governança também foi introduzida na segunda edição, revista e ampliada, do livro Entre modernité et mondialisation. Leçons d'histoire de la philosophie du droit et de l'État, publicado em 2004, em que há todo um capítulo dedicado ao seu exame, como alternativa, no plano global, ao direito internacional. ${ }^{18}$ Nesse momento, a governança global é abordada como uma alternativa à concepção clássica do processo de tomada de decisão jurídica em matéria de relações internacionais. Contudo, André-Jean Arnaud ressalvava que isso somente seria viável mediante condições de implementação e de controle que, em seu entendimento, ainda estariam ausentes no contexto da publicação dessa obra. ${ }^{19}$ Em tal análise, já se expressa, com muita clareza, a preocupação de Arnaud com a questão relativa à participação democrática em nível global, matéria que será retomada, dez anos mais tarde, em La gouvernance. Un outil de participation. ${ }^{20}$ Em 2005, a governança é novamente enfocada por André-Jean Arnaud em sua contribuição para o livro Construire des gouvernances, organizado por Gérman

da noção de governança no âmbito dos "conflitos territorializados" a partir de uma discussão atenta aos atores locais e ao modo de atuação das autoridades públicas nessa seara. Cf. CAPELLER, Wanda; SIMOULIN, Vincent. La gouvernance: du programme de recherche à la transdisciplinarité (Présentation). Droit et Société, n. 54, p. 301305, 2003; SIMOULIN, Vincent. La gouvernance et l'action publique: le succès d'une forme simmélienne. Droit et Société, n. 54, p. 307-326, 2003; BARON, Catherine. La gouvernance: débats autour d'un concept polysémique. Droit et Société, n. 54, p. 329-349, 2003; ISLA, Anne. Pour une économie institutionnelle et organisationnelle du droit: la gouvernance dans l'Union européenne. Droit et Société, n. 54, p. 353-373, 2003; DUPUY, Claude; LEROUX, Isabelle; WALLET, Frédéric. Conflits, négociation et gouvernance territoriale. Droit et Société, n. 54, p. 377-396, 2003.

16 Cf. ARNAUD, André-Jean. Critique de la raison juridique 2. Gouvernants sans frontières. Entre mondialisation et post-mondialisation. Paris: LGDJ, 2003. p. 330 e ss.

17 Cf. ARNAUD, André-Jean. Critique de la raison juridique 2. Gouvernants sans frontières. Entre mondialisation et post-mondialisation, p. 332-355.

18 Cumpre notar que a análise sobre a governança é incluída no capítulo 7 da segunda edição do livro Entre modernité et mondialisation.

19 Cf. ARNAUD, André-Jean. Entre modernité et mondialisation. Leçons d'histoire de la philosophie du droit et de l'État, p. 222.

20 Cf. ARNAUD, André-Jean. Entre modernité et mondialisation. Leçons d'histoire de la philosophie du droit et de l'État, p. 225 e ss. Sobre essa questão, ver: HELD, David. Democracy and the Global Order: from the Modern State to Cosmopolitan Governance. Stanford: Stanford University Press, 1995. p. 141 e ss. 
Novos Estudos Jurídicos

Solinis. ${ }^{21}$ No ano de 2007, o tema é retomado por Arnaud em um artigo publicado em coautoria com Roger Cotterrell sobre a questão do multiculturalismo. ${ }^{22}$ Ele também é amplamente tratado no Dictionnaire de la globalisation, publicado, sob a direção de Arnaud, em 2010. Em um verbete escrito com Vincent Simoulin, ele focaliza a governança em termos conceituais. ${ }^{23}$ Em seguida, o conceito passa a ser enfocado a partir de suas principais formas de expressão. Assim, a "boa governança" é analisada por André-Jean Arnaud, ${ }^{24}$ a "governança global"25 é examinada por Marc Delplanque e, finalmente, a "governança empresarial" é focalizada por Beinan Xue-Bacquet e Gabriel Collets. ${ }^{26}$ A importância dada ao conceito de governança nessa obra coletiva reflete a intensa preocupação que André-Jean Arnaud sempre Ihe dispensou, de modo a, inclusive, promover sua difusão no debate francês. ${ }^{27}$

Em sua última obra, intitulada La gouvernance. Un outil de participation, AndréJean Arnaud enfoca a governança especialmente em termos de um instrumento de participação na tomada de decisões complexas, no contexto regulatório contemporâneo, com significativo potencial de democratização destas. ${ }^{28}$ Atento à polissemia encontrada no conceito de governança, assim como à necessidade de delimitá-lo em relação a outros que lhe são próximos - tais como o de governo, de governabilidade e de governamentalidade -, Arnaud também procura explicitar suas diversas formas de expressão como experiência concreta. ${ }^{29}$ Por conseguinte,

21 Cf. ARNAUD, André-Jean. Chercheur et décideur au coude à coude: un modèle de gouvernance. In: SOLINIS, Gérman (Org.). Construire des gouvernances: entre citoyens, décideurs et scientifiques. Bruxelles: Peter Lang, 2005, p. $165-186$

22 Cf. ARNAUD, André-Jean; COTTERRELL, Roger. Comment penser le multiculturalisme en droit? L'Observateur des Nations Unies, v. 23, n. 2, p. 30 e 32, 2007.

23 Cf. ARNAUD, André-Jean; SIMOULIN, Vincent. Gouvernance. In: ARNAUD, André-Jean (Dir.). Dictionnaire de la globalisation - droit, science politique, sciences sociales. Paris: LGDJ, 2010. p. 266-269.

24 Cf. ARNAUD, André-Jean. Gouvernance (Bonne-). Gouvernance. In: ARNAUD, André-Jean (Dir.). Dictionnaire de la globalisation - droit, science politique, sciences sociales. Paris: LGDJ, 2010. p. 269-270.

25 Cf. DELPLANQUE, Marc. Gouvernance globale. In: ARNAUD, André-Jean (Dir.). Dictionnaire de la globalisation droit, science politique, sciences sociales. Paris: LGDJ, 2010. p. 272-275.

26 Cf. XUE-BACQUET, Beinan; COLLETS, Gabriel. Gouvernance d'entreprise. In: ARNAUD, André-Jean (Dir.). Dictionnaire de la globalisation - droit, science politique, sciences sociales. Paris: LGDJ, 2010. p. $270-272$.

27 Note-se que, na versão brasileira do dicionário, organizada por André-Jean Arnaud e Eliane Botelho Junqueira, constam os verbetes "governança" e "boa governança", de autoria de André-Jean Arnaud, e "governança global", de autoria de Marc Delplanque, o que atesta sua preocupação em difundir o conceito também no Brasil. A esse respeito, ver também: ARNAUD, André-Jean; CAPELLER, Wanda. A força do Estado em face da globalização. In: SOUTO, Cláudio; FALCÃO, Joaquim (Org.). Sociologia e direito: textos básicos para a disciplina de sociologia jurídica. 2. ed. São Paulo: Pioneira Thomson, 2002. p. 229-246.

28 Para uma definição sintética de governança, ver, por exemplo: ARNAUD, André-Jean; SIMOULIN, Vincent. Gouvernance, p. 266-269; DURAN, Patrice. Gouvernance. Revue Politiques et Management Public, v. 16, n. 4, p. 3-4, 1998; CAPELLER, Wanda; SIMOULIN, Vincent. La gouvernance: du programme de recherche à la transdisciplinarité (Présentation). Droit et Société, n. 54, p. 301-305, 2003.

29 Acerca do caráter polissêmico do conceito de governança, ver, por exemplo: BARON, Catherine. La gouvernance: débats autour d'un concept polysémique. Droit et Société, n. 54, p. 329-349, 2003; SIMOULIN, Vincent. La 
diferentemente do que acontecia em textos anteriores, nos quais a governança era enfocada preponderantemente a partir do plano regional e global, ${ }^{30}$ nesse livro, ela é amplamente analisada nos planos da gestão corporativa/empresarial das relações globais, dos blocos regionais, dos Estados nacionais e, finalmente, no contexto local. ${ }^{31}$

\section{ANDRÉ-JEAN ARNAUD E O EXAME DO FENÔMENO DA GOVERNANÇA EM SUAS MÚLTIPLAS FORMAS DE EXPRESSÃO}

Apesar de ostentarem uma miríade de abordagens distintas acerca da governança, as análises sociológicas tendem a focalizá-la, conceitualmente, a partir da ênfase em suas múltiplas formas de expressão. ${ }^{32}$ Jacques Chevallier, por exemplo, ressalta que uma compreensão adequada da governança, além da problematização da clivagem entre público e privado, implicaria apreendê-la a partir de seus vários níveis (internacional, regional, nacional e local) de ação coletiva (multi-level Governance). ${ }^{33}$ Em sentido semelhante, Arnaud, ao sublinhar as várias facetas de expressão do fenômeno da governança, observa, inclusive, o caráter problemático de se utilizar o termo no singular. ${ }^{34}$ Essa preocupação em explicitar a variedade das

gouvernance: du programme de recherche à la transdisciplinarité (Présentation). Droit et Société, n. 54, p. 301305, 2003; LE ROY, Étienne. Gouverner la néo-modernité africaine? Cahiers d'anthropologie du droit - numéro spécial (Droit, gouvernance et développement durable). Paris: Karthala, 2005. p. 186; VILLAS BÔAS FILHO, Orlando. A governança em suas múltiplas formas de expressão: o delineamento conceitual de um fenômeno complexo. Revista Estudos Institucionais, v. 2, n. 2, p. 697, 2016; VILLAS BÔAS FILHO, Orlando. O impacto da governança sobre a regulação jurídica contemporânea: uma abordagem a partir de André-Jean Arnaud. REDES - Revista Eletrônica Direito e Sociedade, v. 4, n. 1, p. 151, 153 e 166, 2016. Acerca da perspectiva de Étienne Le Roy, ainda pouco difundida no Brasil, ver: VILLAS BÔAS FILHO, Orlando. A regulação jurídica para além de sua forma ocidental de expressão: uma abordagem a partir de Étienne Le Roy. Revista Direito \& Práxis, v. 6, n. 12, p. 159-195, 2015; VILLAS BÔAS FILHO, Orlando. Juridicidade: uma crítica à monolatria jurídica como obstáculo epistemológico. Revista da Faculdade de Direito da USP, v. 109, p. 281-325, jan.-dez. 2014.

30 A respeito, ver, sobretudo: ARNAUD, André-Jean. De la régulation par le droit à l'heure de la globalisation. Quelques observations critiques. Droit et Société, n. 35, p. 32-35, 1997; ARNAUD, André-Jean. Entre modernité et mondialisation. Leçons d'histoire de la philosophie du droit et de l'État, p. 217 e ss; ARNAUD, André-Jean. Critique de la raison juridique 2. Gouvernants sans frontières. Entre mondialisation et post-mondialisation, p. 330 e ss.

31 Cf. ARNAUD, André-Jean. La gouvernance. Un outil de participation, p. 27 e ss.

32 A respeito, ver: VILLAS BÔAS FILHO, Orlando. A governança em suas múltiplas formas de expressão: o delineamento conceitual de um fenômeno complexo. Revista Estudos Institucionais. v. 2, n. 2, p. 670-706, 2016. Abordagens concisas, porém bastante elucidativas acerca da governança, podem ser encontradas no Dictionnaire de la globalisation, publicado sob a direção de André-Jean Arnaud. No contexto da discussão anglófona ver, por exemplo: HELD, David. Democracy and the Global Order: from the Modern State to Cosmopolitan Governance. Stanford: Stanford University Press, 1995; HELD, David. Reframing Global Governance: Apocalypse Soon or Reform! New Political Economy, v. 11, n. 2, p. 157-176, jun. 2006.

33 Cf. CHEVALLIER, Jacques. L'État post-moderne. 3. éd. Paris: LGDJ, 2008. p. 240. A respeito, ver: SUPIOT, Alain. La gouvernance par les nombres. Cours au Collège de France (2012-2014). Paris: Fayard, 2015. p. 215 e ss.; DELPEUCH, Thierry; DUMOULIN, Laurence; GALEMBERT, Claire de. Sociologie du droit et de la justice. Paris: Armand Colin, 2014. p. 167.

34 Cf. ARNAUD, André-Jean. Critique de la raison juridique 2. Gouvernants sans frontières. Entre mondialisation et post-mondialisation, p. 333. 
formas expressivas da governança estrutura o já citado livro La gouvernance. Un outil de participation, no qual André-Jean Arnaud sublinha o impacto da governança na erosão do modelo top-down de decisão e, especialmente, seu potencial como instrumento de participação no exercício da autoridade política, econômica e/ou administrativa na gestão dos negócios comuns nos níveis global, regional, nacional, local/territorial e empresarial, abrangendo, ademais, todos os setores (público e privado), especialmente a sociedade civil. ${ }^{35}$

André-Jean Arnaud enfoca, preliminarmente, a progressiva expansão e imposição da governança empresarial como modelo de gestão da complexidade. ${ }^{36}$ Sublinha, assim, que a governança empresarial expressaria um conjunto de procedimentos e de estruturas cuja finalidade seria gerir eficazmente os negócios empresariais de modo a assegurar transparência e equilíbrio de poderes entre administradores, proprietários e seus representantes. ${ }^{37}$ Essa tendência de gestão, que expressaria a superação da tradicional onipotência patronal mediante a introdução massiva de um conjunto de stakeholders, seria passível de implementação a partir da instauração de mecanismos internos e externos de controle. ${ }^{38}$ Deste modo, a governança empresarial se integraria a um conjunto de dispositivos de regulação econômica e financeira com a finalidade de assegurar a boa gestão das empresas em um contexto marcado pela globalização econômica. ${ }^{39}$

Em seguida, Arnaud ressalta a passagem (não ocasional) da corporate governance para a global governance. Para tanto, destaca que o estabelecimento das principais instituições financeiras internacionais em Washington, quando do término da Segunda Guerra Mundial, teria ocasionado a natural influência do

35 Cf. ARNAUD, André-Jean. La gouvernance. Un outil de participation, p. 279. Para uma análise da governança na obra de André-Jean Arnaud, ver, por exemplo: VILLAS BÔAS FILHO, Orlando. O impacto da governança sobre a regulação jurídica contemporânea: uma abordagem a partir de André-Jean Arnaud. REDES - Revista Eletrônica Direito e Sociedade, v. 4, n. 1. p. 145-171, 2016; VILLAS BÔAS FILHO, Orlando. As transformações da regulação jurídica na sociedade contemporânea: a governança como paradigma. Revista Direito GV, v. 12, n. 1, p. 251-259, jan.-abr. 2016.

36 Sobre a governança empresarial, ver: XUE-BACQUET, Beinan; COLLETS, Gabriel. Gouvernance d'entreprise, p. 270-272.

37 Cf. ARNAUD, André-Jean. La gouvernance. Un outil de participation, p. 33. A respeito, ver: MOREAU DEFARGES, Philippe. La gouvernance, p. 32-36.

38 Para uma análise relativa à responsabilidade social da empresa e da governança solidária no Brasil, ver: CAPELLER, Wanda. RSE et gouvernances solidaires au Brésil: entre nouvelles formes de socialité et nouveaux espaces publiques. Sociologies Pratiques, n. 18, p. 79-90, 2009.

39 Cf. ARNAUD, André-Jean. La gouvernance. Un outil de participation, p. 47. A respeito, ver, por exemplo: MOREAU DEFARGES, Philippe. La gouvernance, p. 35; SUPIOT, Alain. L'Esprit de Philadelphie. La justice sociale face au marché total. Paris: Seuil, 2010. p. 77-78; SUPIOT, Alain. La gouvernance par les nombres. Cours au Collège de France (2012-2014), p. 157 e ss. 
ambiente e da cultura econômica dos EUA na montagem de tais instituições. Como decorrência, a governança global teria sido concebida, em seu conjunto, como a gestão dos negócios mundiais no nível das organizações e das agências internacionais. Nesse sentido, o funcionamento de tais instituições (egressas de Bretton Woods) consistiria essencialmente no enquadramento da atividade soberana dos Estados pelos regimes multilaterais de governança, a partir dos princípios componentes do que se convencionou designar "Consenso de Washington": disciplina fiscal; abertura comercial; estímulo a investimentos estrangeiros; privatização de empresas públicas; desregulação e respeito ao direito de propriedade. ${ }^{40}$

Contudo, Arnaud enfatiza que a governança global não seria apenas um instrumento adstrito ao âmbito financeiro, uma vez que assegurar boas relações no plano internacional permitiria, acima de tudo, garantir a "paz mundial". Assim, nessa perspectiva, a governança global assumiria também a dimensão estratégica de promoção da segurança mundial a partir do impulso à cooperação, ao entendimento e à moderação mútua entre os Estados nacionais, o que, segundo o autor, estaria expresso nos capítulos VI e VII da Carta da ONU, os quais tratam da resolução pacífica dos conflitos e divergências e das ações relativas às ameaças à paz, da ruptura da paz e dos atos de agressão. ${ }^{41}$ Nesse contexto, ao destacar que a governança implica a superação de uma forma de gestão piramidal e autoritária, Arnaud sublinha que ela expressaria a substituição progressiva de um sistema top-down de tomada de decisão por um sistema bottom-up, caracterizado pela ausência de uma produção normativa ordenada e sem atos de governo impostos a partir de instâncias centrais e de modo verticalizado. ${ }^{42}$

É certo que, seguindo as considerações de Laura Nader e Ugo Mattei, não se pode descartar que essas proclamadas virtudes da governança global possam figurar como sustentação retórica a uma "reabilitação moral do imperialismo".

40 Cf. ARNAUD, André-Jean. La gouvernance. Un outil de participation, p. 61-63. A respeito, ver: HELD, David. Reframing Global Governance: Apocalypse Soon or Reform! New Political Economy, v. 11, n. 2, p. 157-176, jun. 2006; DELPLANQUE, Marc. Gouvernance globale, p. 272-275; MOREAU DEFARGES, Philippe. La gouvernance, p. 42-49.

41 Cf. ARNAUD, André-Jean. La gouvernance. Un outil de participation, p. 74-79. A respeito, ver: MOREAU DEFARGES, Philippe. La gouvernance, p. 26-27 e 44.

42 Cf. ARNAUD, André-Jean. La gouvernance. Un outil de participation, p. 80 e 90 . Sobre essa temática, ver também: ARNAUD, André-Jean. Entre modernité et mondialisation. Leçons d'histoire de la philosophie du droit et de l'État, p. 142 e ss.; ARNAUD, André-Jean. Critique de la raison juridique 2. Gouvernants sans frontières. Entre mondialisation et post-mondialisation, p. 177 e ss.; COMMAILLE, Jacques. À quoi nous sert le droit?. Paris: Gallimard, 2015. p. 30. 
Segundo os autores, a partir de representações falsas que serviriam apenas para reforçar a supremacia das potências hegemônicas, a ideia de "boa governança" se expressaria, no plano global, como uma espécie de "espinha dorsal" (backbone) dos argumentos mobilizados para legitimar a pilhagem (plunder) das nações subalternas pelas hegemônicas. Logo, na perspectiva de Nader e Mattei, o projeto de governança mundial, atualmente imposto pelo neoliberalismo, transformaria, mediante o uso do direito, as instituições de Bretton Woods, concebidas originalmente como mecanismos de estabilização financeira, em agentes de desestabilização política. Enfatizam, com isso, toda uma dimensão instrumentalizada da governança para a sustentação das relações assimétricas tecidas entre as nações hegemônicas e as subalternas. ${ }^{43}$

André-Jean Arnaud também analisa a governança no âmbito dos blocos regionais, enfocando especialmente a experiência da gouvernance européenne. ${ }^{44}$ Assim, procura especificar a particularidade da experiência europeia diante da ocorrida nos demais blocos regionais, em que se observa uma articulação de caráter essencialmente econômico e sem pretensão política. ${ }^{45}$ Sublinha, entretanto, as diversas dificuldades que expressam as defasagens entre o que se proclama no plano ideal e o que se realiza no plano real. ${ }^{46}$ Segundo ele, o cidadão ordinário

43 MATTEI, Ugo; NADER, Laura. Plunder: when the rule of law is illegal. Oxford: Blackwell Publishing, 2008, p. 5; 17-18; 22-23; 59 e 218. A respeito, ver também: EBERHARD, Christoph. Le droit au miroir des cultures. Pour une autre mondialisation. Paris: LGDJ, 2010. p. 191; EBERHARD, Christoph. O direito no mundo globalizado: em direção à "boa governança" através do diálogo intercultural. Direito, Estado e Sociedade, n. 33, p. 10, 2008. Cumpre aludir aqui à questão da governança mundial do fluxo migratório. Segundo Catherine Wihtol de Wenden, "la gouvernance mondiale des migrations, qui viendrait apporter de la rationalité aux politiques des États, est surtout vécue comme une atteinte à la souveraineté dans les grands pays d'immigration car elle mettrait fin à la situation actuelle - que l'on pourrait qualifier de 'far west' migratoire - où seuls les pays les plus puissants fixent les règles du droit d'émigrer." WIHTOL DE WENDEN, Catherine. Le droit d'émigrer. Paris: CNRS Éditions, 2013. p. 45. Essa observação é particularmente oportuna no momento atual, marcado pela emergência de uma política externa fortemente unilateralista nos EUA, em virtude da eleição de Donald Trump. As polêmicas engendradas recentemente pela política americana de imigração mostram o quanto esta última está diametralmente oposta a uma "governança mundial das migrações". Se levada efetivamente em consideração como forma de racionalização das políticas estatais, a "governança do fluxo migratório" escancara o caráter despropositado de iniciativas como, por exemplo, a construção de um muro na fronteira dos EUA com o México. Acerca da governança da migração global, ver: BETTS, Alexander. Introduction: global migration governance. In: (Ed.). Global migration governance. Oxford: Oxford University Press, 2011. p. 1-33. Acerca das restrições impostas ao fluxo migratório em virtude de políticas de controle direcionadas especialmente ao terrorismo, ver: DELMAS-MARTY, Mireille. Libertés et sûreté dans un monde dangereux. Paris: Seuil, 2010. p. 243-248; WIHTOL DE WENDEN, Catherine. Faut-il ouvrir les frontières? Paris: Presses de Science Po, 2014.

44 Cf. ARNAUD, André-Jean. La gouvernance. Un outil de participation, p. 114 e ss.

45 Cf. ARNAUD, André-Jean. La gouvernance. Un outil de participation, p. 123-130. Acerca da experiência europeia no quadro da governança regional, ver: DELMAS-MARTY, Mireille. Les forces imaginantes du droit. Le relatif et l'universel. Paris: Seuil, 2004. p. 71-72 e 80-82.

46 Esse descompasso entre a projeção ideal e as vicissitudes reais experimentadas pelos blocos regionais ganhou, no contexto europeu, especial evidência em virtude do Brexit. Aliás, a recente retirada dos EUA do Acordo Transpacífico (Trans-Pacific Partnership) também seria ilustração desse descompasso. 
estaria, por via de regra, distante do funcionamento da governança. Além disso, em sua abordagem, enfocam-se as ambivalências (e, portanto, os perigos) das redes de ação pública e a importância atribuída à expertise no contexto da governança europeia. ${ }^{47}$ É justamente no contexto de sua análise da governança regional que o autor focaliza a experiência desenvolvida no Mercosul.

A análise da governança no plano nacional é a que mais diretamente se atrela a questões culturais. Assim, a partir de um breve contraste entre a experiência político-administrativa norte-americana e a francesa, Arnaud ressalta que a representação da governança como uma ameaça à soberania estatal se expressa, sobretudo, em países nos quais se verifica uma visão cultural centralista do Estado moderno. Contudo, procura sublinhar o fato de que o Estado não poderia mais ser visto como a única instância detentora do poder, ${ }^{48}$ de modo que, com a governança, afigurar-se-ia possível gerir as questões públicas para além do direito estatal, o que, em outras palavras, expressaria a progressiva passagem de uma ação política outrora fundada no governo para outra amparada na governança. ${ }^{49}$ Decorreria daí, inclusive, o declínio da concepção top-down que atribui apenas aos governantes a criação do "dever-ser". Observar-se-ia, portanto, a progressiva substituição, no debate jurídico, dos conceitos clássicos de "governo", "lei" e "regulamentação" pelos de "governança", "políticas públicas", "ação direta", "resolução de conflitos" e, especialmente, "regulação".50

47 Cf. ARNAUD, André-Jean. La gouvernance. Un outil de participation, p. 145 e ss. A respeito, ver: ISLA, Anne. Pour une économie institutionnelle et organisationnelle du droit: la gouvernance dans l'Union européenne. Droit et Société, n. 54, p. 353-373, 2003.

48 É possível afirmar que, sob esse aspecto, a análise de André-Jean Arnaud problematiza concepções como a de Pierre Bourdieu que, inspirado em Weber, define o Estado como instância detentora do monopólio legítimo da violência física e simbólica. Cf. BOURDIEU, Pierre. Esprits d'État [Genèse et structure du champ bureaucratique]. Actes de la Recherche en Sciences Sociales, v. 96-97, p. 49-62, Mars. 1993; BOURDIEU, Pierre. Sur l'État. Cours au Collège de France 1989-1992. Paris: Seuil, 2012. p. 14; 139; 199; 204; 545 e 587. Para uma problematização da perspectiva estatocêntrica de Bourdieu, ver: COMMAILLE, Jacques. À quoi nous sert le droit?, p. 30; A respeito, ver também: CHEVALLIER, Jacques. L'État post-moderne, p. 237-242. Para uma comparação entre as perspectivas de Arnaud e Bourdieu, no que concerne à noção de campo jurídico, ver: CAPELLER, Wanda. De que lugar falamos? Retomando um velho papo sobre o Direito e a Sociologia. Revista de Estudos Empíricos em Direito, v. 2, n. 2, p. 18, jan. 2015. Para uma apresentação introdutória da perspectiva de Jacques Commaille, ver: VILLAS BÔAS FILHO, Orlando. A juridicização e a judiciarização enfocadas a partir da "sociologia política do direito" de Jacques Commaille. Revista Brasileira de Sociologia do Direito, ABraSD, v. 2, n. 2, p. 56-75, jul.-dez. 2015.

49 ARNAUD, André-Jean. La gouvernance. Un outil de participation, p. 179. A respeito, ver: ARNAUD, AndréJean. Entre modernité et mondialisation. Leçons d'histoire de la philosophie du droit et de l'État, p. 146 e ss.; CHEVALLIER, Jacques. L'État post-moderne, p. 237-238; SUPIOT, Alain. L'Esprit de Philadelphie. La justice sociale face au marché total, p. 77-78.

50 Cf. ARNAUD, André-Jean. La gouvernance. Un outil de participation, p. 180. Para uma definição do conceito de regulação, ver, por exemplo: ARNAUD, André-Jean. De la régulation par le droit à l'heure de la globalisation. Quelques observations critiques, p. 11-35; CHEVALLIER, Jacques. La régulation juridique en question. Droit et Société, n. 49, p. 827-846, 2001; CHEVALLIER, Jacques. L'État post-moderne, p. 61-62. 
Para analisar a governança territorial, André-Jean Arnaud parte da clássica obra de James Nathan Rosenau. ${ }^{51}$ Assim, sublinha a dificuldade de definição do que seja a governança territorial, especialmente em virtude do desaparecimento do que outrora se designava de "ordem territorial" em virtude da explosão das fronteiras locais, da complexidade engendrada pela progressiva desvinculação das políticas territoriais dos limites jurisdicionais e das escalas tradicionais e da multiplicação dos atores em interação. Deste modo, conforme se verá a seguir, afirma que a expressão recobriria o conjunto de situações de cooperação entre autoridades públicas, atores privados, associações e cidadãos, não ordenados hierarquicamente, envolvidos na construção, na gestão ou na representação dos territórios em que vivem e em relação ao ambiente exterior. ${ }^{52}$

\section{A EXPERIÊNCIA DO MERCOSUL NO PLANO DA GOVERNANÇA REGIONAL}

Conforme mencionado, ao longo de seu exame acerca da governança no âmbito regional, André-Jean Arnaud descentra-se da União Europeia e, a partir de uma abordagem contrastada, especialmente no que concerne ao deficit de participação dos cidadãos, enfoca a experiência desenvolvida no Mercosul..$^{53}$ Considerando, evidentemente, as particularidades desses dois blocos, o autor aponta os paralelos existentes entre eles, principalmente no que tange à pretensão de construção de dois espaços regionais de cooperação transnacional com aspirações análogas de integração econômica e de constituição de um projeto político mais global. A esse respeito, enfatiza que, apesar dos indiscutíveis avanços ocorridos tanto na União Europeia como no Mercosul, ambos os blocos consistiriam, ainda, em laboratórios de experimentação para a governança regional. A partir desse contraste, sublinha que o deficit de participação real

51 Cf. ARNAUD, André-Jean. La gouvernance. Un outil de participation, p. 223.

52 Cf. ARNAUD, André-Jean. La gouvernance. Un outil de participation, p. 224-227.

53 Cf. ARNAUD, André-Jean. La gouvernance. Un outil de participation, p. 158-166. Acerca do contraste entre a experiência do Mercosul e da União Europeia, ver, por exemplo: VENTURA, Deisy. As assimetrias entre o Mercosul e a União Europeia: os desafios de uma associação inter-regional. São Paulo: Manole, 2003; VENTURA, Deisy. La gouvernance démocratique et l'intégration économique. Regards croisés entre le Mercosur et l'Union européenne. Droit et société. n. 59, p. 93-103, 2005; VENTURA, Deisy. Mercosur. p. 352-354. In: ARNAUD, André-Jean (Dir.). Dictionnaire de la globalisation - droit, science politique, sciences sociales. Paris: LGDJ, 2010. p. 269-270; D'ARCY, François. Les perspectives politiques du Mercosur: comparaison avec l'Union européenne. Droit et Société. n. 59, p. 19-35, 2005; DELMAS-MARTY, Mireille. Les forces imaginantes du droit. Le relatif et l'universel, p. 81. Para uma análise corrosiva que sublinha a subordinação da preocupação social aos interesses liberais na construção da União Europeia, ver: DENORD, François; SCHWARTZ, Antoine. L'Europe sociale n'aura pas lieu. Paris: Raisons d'agir, 2009. 
dos cidadãos apareceria como o principal entrave a um desenvolvimento mais consequente da governança regional, entendida como dinâmica complexa das relações e inter-relações transformadoras que articulam instituições, Estadosmembros, sociedade civil, grupos de interesse, lobbies e redes sociais. ${ }^{54}$

Em sua análise, Arnaud contrasta as experiências do Mercosul e da União Europeiasem, entretanto, elevarestaúltima ao patamardeummodelo paradigmático a ser replicado na América Latina. Ao contrário, atento à especificidade que caracteriza a emergência do Mercosul, realça os motivos fundamentais que nortearam a sua criação: a) a tentativa de desenvolver e assegurar a democracia após um período marcado por ditaduras violentas na região; b) a promoção da cooperação entre os países sul-americanos, especialmente a partir da criação de uma união aduaneira. ${ }^{55}$ Aliás, cumpre notar que, já em 2005, em um dossiê que coordenou sobre o Mercosul para a revista Droit et Société, André-Jean Arnaud, manifestando-se criticamente com relação ao caráter problemático do mimetismo institucional, ressaltava que "les modèles ne s'exportent pas. Chaque culture est une culture, et chacune a son histoire, faite de passé, mais aussi de présent et, surtout, du projet qu'elle forme pour son avenir". ${ }^{56}$

Referindo-seà integração regional promovida pelo Mercosul, Arnaud sublinha que ela se caracterizaria por engendrar uma regulação intermediária entre o plano nacional e o global no que concerne a questões vitais que transcendem a órbita dos Estados nacionais, o que, em seu entendimento, seria indicativo de que, em termos conceituais, a experiência da governança, e não a do governo, pautaria a produção normativa nesse bloco regional. No bojo dessa análise, ressalta que o Mercosul, tal como a União Europeia, consistiria em um espaço de governança regional em construção que, malgrado seus avanços, ainda careceria de uma participação mais efetiva nas tomadas de decisão. Assim, aludindo à instituição do Fórum Consultivo Econômico Social (FCES), sustenta que o Mercosul teria conseguido institucionalizar a participação do setor público e da sociedade civil organizada. Entretanto, ao enfatizar o caráter apenas consultivo do FCES, Arnaud

54 Cf. ARNAUD, André-Jean. La gouvernance. Un outil de participation, p. 158-166.

55 Cf. ARNAUD, André-Jean. La gouvernance. Un outil de participation, p. 160.

56 ARNAUD, André-Jean. Présentation au dossier "Mercosur. Une voie différente de l'Union européenne?". Droit et Société, n. 59, p. 11, 2005. 
não envereda por um idealismo ingênuo no que concerne à eficácia desse Fórum como instrumento de promoção de uma participação mais efetiva na tomada das decisões que ocorrem no Mercosul. ${ }^{57}$

Nesse particular, as considerações de André-Jean Arnaud apresentam clara convergência com as conclusões consignadas na expressiva análise feita por Deisy Ventura acerca do Mercosul. Mediante uma comparação entre as convergências e divergências entre esse bloco regional e a União Europeia, a autora capitula uma série de aspectos próprios da experiência da integração latino-americana que precisam ser considerados por uma abordagem que, tal como a de Arnaud, a inscreve no âmbito da governança regional. ${ }^{58}$ Por esse motivo, será feita, a seguir, uma breve digressão pela análise dessa autora.

No que tange às divergências entre esses dois blocos regionais, Deisy Ventura, em primeiro lugar, referindo-se à questão da expertise, alude à falta de transparência como uma característica que, entre outras, marcaria o Mercosul. Por isso, salienta que a confidencialidade (que, conforme estabelecido pelo art. 12 da Resolução GMC 26/2001, deveria ser excepcional) teria, progressivamente, se transformado em regra na circulação das informações. ${ }^{59}$ Ora, se se considera que a transparência constitui um aspecto fundamental da governança, fica claro o comprometimento desta última no âmbito da experiência latino-americana. ${ }^{60}$ Em segundo lugar, no que concerne ao direito, Deisy Ventura, contrastando o arcabouço normativo da União Europeia e o do Mercosul, destaca que o segundo, diferentemente do que ocorre no primeiro, não consistiria, em sentido próprio, em uma ordem jurídica. ${ }^{61}$ Conforme bem observa a autora, não se trata de propor uma transposição artificial do modelo institucional europeu para América Latina,

57 Cf. ARNAUD, André-Jean. La gouvernance. Un outil de participation, p. 161-162.

58 Cf. VENTURA, Deisy. La gouvernance démocratique et l'intégration économique. Regards croisés entre le Mercosur et l'Union européenne, p. 96-104. Para uma análise mais profunda do contraste entre Mercosul e União Europeia, ver: VENTURA, Deisy. As assimetrias entre o Mercosul e a União Europeia: os desafios de uma associação interregional. São Paulo: Manole, 2003. Especialmente a primeira parte.

59 Cf. VENTURA, Deisy. La gouvernance démocratique et l'intégration économique. Regards croisés entre le Mercosur et l'Union européenne, p. 97.

60 Acerca da governança como promotora de transparência, ver, por exemplo: MOREAU DEFARGES, Philippe. La gouvernance, p. 105; XIFRA, Jordi. Qué es transparencia (si existe en relaciones públicas)? In: FARIAS, Luiz Alberto de; LOPES, Valéria de Siqueira Castro (Orgs.). Comunicação, governança e organizações. Porto Alegre: EDIPUCRS, 2016. p. 19-30; ORTIZ, Laure. Préface. In: ARNAUD, André-Jean. La gouvernance. Un outil de participation, p. VII. Para uma análise do princípio da transparência no âmbito da governança e sua relação com a democracia, ver: ROSANVALLON, Pierre. Légitimité démocratique et gouvernance. Chroniques de la gouvernance 2009-2010. Paris: Éditions Charles Léopold Mayer, 2009. p. 14.

61 A respeito, ver: VENTURA, Deisy. A ordem jurídica do Mercosul. Porto Alegre: Livraria do Advogado, 1996. p. 41 e ss. 
mas apenas enfatizar que o Mercosul seria uma estrutura de transição entre uma união aduaneira e um mercado comum de tipo simplificado. ${ }^{62}$ Aliás, conforme ressalta a autora em um texto mais recente, o perfil do Mercosul se aproximaria mais do modelo da OMC do que do da União Europeia. ${ }^{63}$

Assim, consideradas essas especificidades, as diferenças entre as experiências do Mercosul e da União Europeia tornam-se flagrantes no tocante à dimensão jurídica. Em primeiro lugar, cumpre notar que o direito comunitário europeu se fundaria no princípio da primazia do direito comunitário sobre os direitos nacionais, na aplicabilidade imediata das normas do direito comunitário e na possibilidade de mobilizar tal direito diretamente, seja no âmbito nacional ou comunitário. Poder-se-ia, por conseguinte, sustentar que se trata de um caso efetivo de transnacionalização do direito. O Mercosul, entretanto, remanesceria um simples acordo intergovernamental de modo a não engendrar uma ordem jurídica autônoma, tal como ocorre no direito comunitário europeu, uma vez que o princípio da primazia do direito da integração sobre os direitos internos dos paísesmembros não teria sido estabelecido e, além disso, as possiblidades de invocar judicialmente as normas estabelecidas pelo Mercosul seriam bastante limitadas. ${ }^{64}$

Ademais, se se considera o perfil do arcabouço normativo do Mercosul como algo atrelado a relações intergovernamentais, percebe-se seu caráter pouco afeto ao tipo de regulação dúctil que forja as relações no âmbito da governança. ${ }^{65}$ Diante da ausência de uma efetiva jurisdição comunitária no âmbito do Mercosul, com a decorrente assunção, pelas jurisdições nacionais dos Estados-membros, da incumbência de decidir os casos em que há conflito entre a regulação emanada do bloco regional latino-americano e o direito interno a cada país, fica claro que, 62 Cf. VENTURA, Deisy. La gouvernance démocratique et l'intégration économique. Regards croisés entre le Mercosur et l'Union européenne, p. 98-99.

63 Cf. VENTURA, Deisy. Mercosur, p. 352.

64 Cf. VENTURA, Deisy. La gouvernance démocratique et l'intégration économique. Regards croisés entre le Mercosur et l'Union européenne, p. 98-99; VENTURA, Deisy. Mercosur, p. 353-354. Aliás, Deisy Ventura sustenta que o Tribunal Permanente de Revisão do Mercosul, criado em 2002 pelo Protocolo de Olivos, não seria tribunal nem permanente, remanescendo, assim, uma simples instância recursiva das decisões dos tribunais ad hoc de arbitragem. A respeito, ver também: ALMEIDA, José Gabriel Assis de. Le cadre normatif du Mercosur. Droit et Société. n. 59, p. 39-53, 2005; ALMEIDA, José Gabriel Assis de. Mercosul: manual de direito da integração. Rio de Janeiro: Lumen Juris, 2001.

65 Para uma análise da soft law como mecanismo de regulação flexível e de significativa incidência no contexto transnacional, ver, por exemplo: CHEVALLIER, Jacques. L'État post-moderne. 3. ed. Paris: LGDJ, 2008. p. 143146; DELMAS-MARTY, Mireille. Le flou du droit. Paris: PUF, 2004. p. 21-25; DELMAS-MARTY, Mireille. Les forces imaginantes du droit (II). Le pluralisme ordonné. Paris: Seuil, 2006. p. 177-178; 189-190 e 266; DELPEUCH, Thierry; DUMOULIN, Laurence; GALEMBERT, Claire de. Sociologie du droit et de la justice, p. 259-261. 
em última análise, são as instituições governamentais internas de cada Estado que acabam por tornar casuisticamente efetivas tais regulações. ${ }^{66}$ É claro que isso não impede a experiência da governança no âmbito do Mercosul, contudo Ihe impõe significativas limitações.

Por fim, cabe notar que a experiência da governança regional expressa pelo Mercosul também encontra significativos óbices em virtude do cenário de fragmentação político-ideológica que tem predominado no contexto latinoamericano. A respeito, Alberto Amaral Júnior observa que o Mercosul teria sido concebido, a partir de um ideário liberal, como uma forma de integração conjunta dos países da região na economia globalizada. Portanto, a criação do bloco estaria associada originalmente ao intuito de estimular a competitividade das economias envolvidas, atrair investimentos e expandir exportações. Assim, diferentemente do que teria ocorrido em experiências anteriores, cujo foco se concentrava na substituição de importações, o propósito que norteou a criação do Mercosul teria sido uma efetiva integração na economia global. No entanto, a incapacidade dos governos do Cone Sul de ampliar e liberalizar o comércio regional e de induzir o setor industrial a criar cadeias produtivas organizadas racionalmente teria engendrado um desvio progressivo do bloco em relação às suas diretrizes iniciais. ${ }^{67}$

Aludindo à suspensão do Paraguai e ao ingresso da Venezuela no Mercosul, Alberto Amaral Júnior procura enfatizar o caráter político-ideológico que passou a reger as relações entre os países componentes desse bloco regional. ${ }^{68}$

66 Conforme nota Deisy Ventura, “l’application du droit du Mercosur, transposé dans l'ordre interne et invoqué devant une juridiction nationale, est à l'image de l'efficacité du système juridique interne : elle en dépend. [...] l'application du droit du Mercosur n'est garantie que lorsqu'il est transposé et qu'on la calque sur celle d'un traité international ordinaire" (VENTURA, Deisy. La gouvernance démocratique et l'intégration économique. Regards croisés entre le Mercosur et I'Union européenne, p. 98).

67 Cf. AMARAL JÚNIOR, Alberto. Fragmentação e integração na América Latina. In: LAGOS, Ricardo (Coord.). A América Latina no mundo: desenvolvimento regional e governança internacional. São Paulo: Editora da Universidade de São Paulo, 2014. p. 53. A respeito, Deisy Ventura já observava, em 2005, que "dans la mesure où l'alternance réelle du pouvoir arrive par l'axe Argentine-Brésil, et où les présidents Lula e Kirschner donnent à l'intégration régionale une dimension idéologique, les voix contre le Mercosur commencent à se lever" (VENTURA, Deisy. La gouvernance démocratique et l'intégration économique. Regards croisés entre le Mercosur et l'Union européenne, p. 95).

68 Segundo Amaral Júnior, "o episódio que culminou com a suspensão do Paraguai e o ingresso da Venezuela no Mercosul evidencia o crescente peso da ideologia nacionalista e populista defendida por Buenos Aires e Caracas nas decisões do bloco regional. Confirmada essa assertiva no futuro, o Mercosul sofrerá uma grande transformação: o objetivo de ampliar o comércio por meio da eliminação das barreiras às importações e fortalecer as cadeias produtivas cederá lugar à persistência do protecionismo em escala regional, cuja dimensão poderá até mesmo elevar-se no curto prazo. É provável, nesse contexto, que o Mercosul seja utilizado como instrumento de contestação aos Estados Unidos no continente americano. Vale lembrar que os projetos políticos que nortearam a criação da Aliança Bolivariana para as Américas (Alba) e do Mercosul são antagônicos e uma eventual 
Dessarte, segundo o autor, "a primitiva concepção que orientou a formação do Mercosul foi completamente perdida por causa dos projetos políticos de alguns governos da região". ${ }^{69}$ Não cabe aqui discutir essa questão. Para os limitados propósitos deste artigo, o que importa notar é o impacto deletério dessa situação na efetiva implementação de uma governança regional. A contaminação políticoideológica, aliada ao deficit de transparência e de participação e também ao caráter juridicamente fluido e pouco efetivo da regulação produzida no âmbito do Mercosul, estabelece um entrave não desprezível à efetivação de uma governança regional em que diversos atores - Estados-membros, instituições, sociedade civil, grupos de interesse, lobbies, redes sociais, etc. - se articulem em dinâmicas complexas. ${ }^{70}$

\section{A EXPERIÊNCIA DO ORÇAMENTO PARTICIPATIVO COMO SISTEMA DE DECISÃO BOTTOM-UP NO ÂMBITO DA GOVERNANÇA TERRITORIAL}

André-Jean Arnaud também examina o orçamento participativo como forma de ilustração concreta da governança territorial/local. Trata-se de uma questão que também permite aquilatar a potencialidade de sua obra para a elucidação de experiências que se desenvolveram expressivamente no Brasil. Aliás, cumpre notar que Arnaud, sem descambar pela apologia acrítica, considera a experiência de Porto Alegre como um caso paradigmático no âmbito de sua abordagem da governança em nível territorial/local. ${ }^{71}$ Trata-se de uma temática que é objeto de uma ampla e complexa literatura especializada no Brasil. Contudo, conforme já ressaltado, o presente artigo não tem a pretensão de enveredar por essa ampla produção teórica nem muito menos pelas diversas discussões que nela se inscrevem. ${ }^{72} \mathrm{O}$ que interessa à

contaminação do Mercosul pelo ideário da Alba teria, certamente, efeitos indesejados" (AMARAL JÚNIOR, Alberto. Fragmentação e integração na América Latina, p. 59-60).

69 AMARAL JÚNIOR, Alberto. Fragmentação e integração na América Latina, p. 53. Aliás, conforme sublinha Deisy Ventura, do ponto de vista político, o Mercosul rivalizaria com a Unasul. Cf. VENTURA, Deisy. Mercosur, p. 352.

70 Acerca dessas características como constitutivas da governança regional, ver: ARNAUD, André-Jean. La gouvernance. Un outil de participation, p. 166. Cumpre notar que diversos autores têm destacado a importância da governança no desenvolvimento regional da América Latina. A respeito, ver, por exemplo: OLIVEIRA, Alessandra Cavalcante. Aliança do Pacífico: desenvolvimento regional e governança internacional. In: LAGOS, Ricardo (Coord.). A América Latina no mundo: desenvolvimento regional e governança internacional. São Paulo: Editora da Universidade de São Paulo, 2014. p. 213224. LOCHAGIN, Gabriel Loretto. Lições latino-americanas para um mundo em crise: apontamentos para a governança internacional da dívida pública. In: LAGOS, Ricardo (Coord.). A América Latina no mundo: desenvolvimento regional e governança internacional. São Paulo: Editora da Universidade de São Paulo, 2014. p. 225-237; SANTISO, Carlos. Parlements et démocratie budgétaire en Amérique Latine. In: BELLINA, Séverine; MAGRO, Hervé; VILLEMEUR, Violaine (Dir.). La gouvernance démocratique. Un nouveau paradigme pour le développement? Paris: Karthala, 2008. p. 223-236.

71 Cf. ARNAUD, André-Jean. La gouvernance. Un outil de participation, p. 228 e ss.

72 Não caberia elencar aqui os diversos autores que - de Leonardo Avritzer à Luciano Fedozzi e Rebecca Abers - enfocam essa questão. A respeito, ver, por exemplo: FEDOZZI, Luciano Joel; MARTINS, André Luis Borges. Trajetória do orçamento participativo de Porto Alegre: representação e elitização política. Lua Nova, n. 95, p. 
presente análise é enfocar o orçamento participativo de Porto Alegre como expressão concreta da governança no nível territorial/local, tal como a conceitua André-Jean Arnaud, para, a partir daí, indicar seu potencial de promoção de um sistema bottomup de decisão. Para tanto, cumpre, em primeiro lugar, que se enfoque o que o autor entende especificamente por governança territorial/local.

Para examinar a governança territorial/local, André-Jean Arnaud recupera a ideia de governança "subnacional", proposta por James Nathan Rosenau. ${ }^{73}$ Nesse sentido, enfatiza, preliminarmente, que a governança territorial, apesar de enfrentar os mesmos desafios que se impõem à transnacional, caracterizarse-ia por não poder se estender para além da jurisdição dos Estados em que ela se exerce. Assim, após sublinhar a dificuldade de definição do que seja a governança territorial - especialmente com o desaparecimento do que outrora se designava de "ordem territorial" em virtude da explosão das fronteiras locais, da multiplicação dos atores em interação e da complexidade engendrada pela progressiva desvinculação das políticas territoriais dos limites jurisdicionais e das escalas tradicionais -, André-Jean Arnaud, retomando uma definição proposta por ele e Vincent Simoulin, afirma que a expressão recobriria o conjunto de situações de cooperação entre autoridades públicas, atores privados, associações e cidadãos, não ordenados hierarquicamente, envolvidos na construção, na gestão ou na representação dos territórios em que vivem e em relação ao ambiente exterior. ${ }^{74}$

É justamente para ilustrar o modo pelo qual se desenvolve concretamente a governança territorial que o autor se propõe a enfocar, em primeiro lugar, seus efeitos transformadores na administração pública local e, em segundo lugar, seu impacto na questão do desenvolvimento sustentável. Portanto, a partir de uma detalhada análise dirigida à realidade brasileira, focaliza, em primeiro lugar, a

181-224, Aug. 2015; CAPELLINI, Gustavo de Almeida; BONACIM, Carlos Alberto Grespan. Governança, governabilidade e coalizão política no processo orçamentário brasileiro. In: GONZÁLEZ, Felipe (Coord.); DAMIANI, Gerson; FERNÁNDEZ-ALBERTOS, José (Orgs.). Governança e democracia representativa. São Paulo: Editora da Universidade de São Paulo, 2017, p. 459-476.

73 Conforme Arnaud "dès la fin du siècle écoulé, James Nathan Rosenau, en même temps qu'il définissait la gouvernance transnationale - on le précisait en parlant de gouvernance globale -, donnait une définition de la gouvernance 'subnationale'” (ARNAUD, André-Jean. La gouvernance. Un outil de participation, p. 223). A respeito, ver: ROSENAU, James. Governança, ordem e transformação na política mundial. In: ROSENAU, James; CZEMPIEL, Ernst-Otto (Org.). Governança sem governo: ordem e transformação na política mundial. Tradução de Sérgio Bath. Brasília: Editora UnB/Imprensa Oficial do Estado, 2000. p. 11-46; CHEVALLIER, Jacques. L'État. Paris: Dalloz, 2011. p. 98.

74 Cf. ARNAUD, André-Jean. La gouvernance. Un outil de participation, p. 224-227. 
experiência do orçamento participativo de Porto Alegre, discutindo em que medida ela expressaria um modelo de governança local em meio ao qual se esboçaria um sistema de decisão de perfil bottom-up em substituição à lógica top-down que se manifesta na dinâmica tradicional das decisões governamentais, ${ }^{75} \mathrm{e}$, em segundo lugar, a experiência da governança no que concerne ao desenvolvimento sustentável na floresta amazônica. ${ }^{76}$

No que tange ao orçamento participativo, André-Jean Arnaud, baseando-se em François Ascher, sustenta que tal experiência poderia ser definida em termos de um processo de participação comunitária fundado sobre um conjunto de instituições que funcionam como mecanismos ou canais aptos a assegurar a participação no curso do processo de decisão em nível municipal. Seria, nesse sentido, a expressão de uma reforma política que ensejaria a participação dos cidadãos nos espaços de ação pública a partir de diversos mecanismos de democracia direta. Desse modo, o orçamento participativo permitiria aos cidadãos influenciarem as decisões relativas às despesas municipais. ${ }^{77}$ Feitas essas considerações, Arnaud assevera que o orçamento participativo de Porto Alegre seria expressão de um modelo paradigmático de boa governança em nível territorial/local, pois promoveria um sistema de decisão de perfil bottom-up em substituição à dinâmica tradicional de viés top-down. ${ }^{78}$

Não cabe reproduzir aqui a descrição minuciosa que André-Jean Arnaud faz da forma de estruturação do orçamento participativo na cidade de Porto Alegre como ilustração de uma boa governança em nível territorial/local. ${ }^{79} \mathrm{O}$ que cumpre realçar é que, para o autor, essa experiência serviria para promover a convergência entre participação e representação democrática, mediante a reabilitação da sociedade civil à qual se outorga poder efetivo de decisão na elaboração e na implementação de políticas públicas. ${ }^{80}$ É bem verdade que, como bem ressalta o autor, não se trata de uma panaceia, posto que diversos obstáculos

75 Segundo Arnaud, "on est en présence d'un système de décision qui vise à inclure une dimension bottom-up, sans ordres ni actes de gouvernement tombant d'en-haut selon la dynamique traditionnelle top-down" (ARNAUD, André-Jean. La gouvernance. Un outil de participation, p. 231). A respeito, ver também: COMMAILLE, Jacques. L'ordre juridique comme désordre politique. Pouvoirs, n. 94, p. 75-86, 2000.

76 Cf. ARNAUD, André-Jean. La gouvernance. Un outil de participation, p. 258-268.

77 Cf. ARNAUD, André-Jean. La gouvernance. Un outil de participation, p. 229.

78 Cf. ARNAUD, André-Jean. La gouvernance. Un outil de participation, p. 233.

79 A respeito, ver: ARNAUD, André-Jean. La gouvernance. Un outil de participation, p. 230-243.

80 Cf. ARNAUD, André-Jean. La gouvernance. Un outil de participation, p. 229. 
comprometem sua efetiva realização. Entre tais obstáculos, Arnaud destaca, em primeiro lugar, problemas ínsitos ao exercício da democracia direta, tais como a ausência de coesão social, o deficit de participação nas reuniões, a limitação de recursos, a dificuldade de conciliar interesses díspares e a possibilidade, sempre presente, de cooptação da participação popular. ${ }^{81}$

Referindo-se às abordagens que, desde há muito tempo, associam democracia local e participação dos cidadãos, André-Jean Arnaud enfatiza que a governança territorial/local, para sua efetiva consecução, demandaria uma reconfiguração dos poderes entre governantes, sociedade civil e mercado, o que engendra o confronto de diversas "racionalidades políticas". ${ }^{82}$ Como decorrência, a governança territorial/local suporia a construção e a manutenção permanente de novos quadros institucionais e o manejo de instrumentos complexos, tais como: procedimentos administrativos e jurídicos, finanças públicas, etc. Nesse sentido, pressuporia o engajamento dos representantes e a participação dos cidadãos e das associações civis (daí, aliás, a necessidade de um processo progressivo de empowerment). ${ }^{83}$ Logo, Arnaud observa que também no plano territorial a governança implica a redefinição das funções públicas tal como foram concebidas tanto pela filosofia jurídica como pela política da época moderna (séculos XVII e XVIII), as quais teriam pautado, desde então, toda a conquista da democracia no Ocidente. ${ }^{84}$

81 Cf. ARNAUD, André-Jean. La gouvernance. Un outil de participation, p. 238-243.

82 Cumpre notar que Arnaud distingue entre participação cidadã direta (exemplificada pelo orçamento participativo) e indireta (expressa a partir de associações sindicais, ONGs etc.). Em meio à participação cidadã indireta estariam inscritos as redes e os movimentos sociais. Cf. ARNAUD, André-Jean. La gouvernance. Un outil de participation, p. 286. A respeito, ver também: CAMPILONGO, Celso Fernandes. Interpretação do direito e movimentos sociais. Rio de Janeiro: Elsevier, 2012. A respeito, ver também: DAMIANI, Gerson; FERNÁNDEZ-ALBERTOS, José. Governança, poder e democracia representativa. In: GONZÁLEZ, Felipe (Coord.); DAMIANI, Gerson; FERNÁNDEZALBERTOS, José (Orgs.). Governança e democracia representativa. São Paulo: Editora da Universidade de São Paulo, 2017, p. 25-32.

83 Cf. ARNAUD, André-Jean. La gouvernance. Un outil de participation, p. 269. Nesse particular, é possível sustentar que a perspectiva de Arnaud se aproxima da de Pierre Rosanvallon. A respeito, ver: ROSANVALLON, Pierre. La légitimité démocratique: impartialité, réflexivité, proximité. Paris: Seuil, 2008. Sobre o caráter polissêmico do conceito de democracia, ver: VILLAS BÔAS FILHO, Orlando. Democracia: a polissemia de um conceito político fundamental. Revista da Faculdade de Direito da USP, v. 108, p. 651-696, jan.-dez. 2013; VILLAS BÔAS FILHO, Orlando. Democracia: estado idílico da política? Revista Brasileira de Ciências Sociais, São Paulo, v. 25, n. 74, p. 183-186, out. 2010. Sobre a importância dos processos de ação coletiva nos quais os atores participam da concepção e da aplicação das normas no âmbito de operações de aprendizagem, ver: COMMAILLE, Jacques. À quoi nous sert le droit?, p. 367 e ss.; COMMAILLE, Jacques. Les enjeux politiques d'un régime de connaissance sur le droit. La sociologie du droit de Georges Gurvitch. Droit et Société, n. 94, p. 560, 2016. 
O presente artigo procurou reconstruir, em linhas gerais, a análise realizada por André-Jean Arnaud acerca das experiências do Mercosul e do orçamento participativo no quadro de sua abordagem do fenômeno da governança. O propósito dessa reconstrução foi realçar o potencial que o quadro analítico desenvolvido pelo autor oferece para a elucidação crítica de experiências concretas inscritas na realidade brasileira. Esse potencial analítico da obra de Arnaud decorre do "espírito de abertura" que o levou a participar ativamente da construção da sociologia jurídica latinoamericana. Conforme salienta Wanda Capeller no prefácio à edição brasileira do livro O direito traído pela filosofia, a obra de Arnaud começou a se difundir na América Latina em um momento de significativas transformações nas realidades jurídicas nos países da região. ${ }^{85}$ Foi nesse momento que Arnaud, interessando-se pela realidade de tais países, especialmente o Brasil, contribuiu decisivamente para o enriquecimento do arsenal conceitual e teórico do debate jurídico e para o aguçamento do olhar crítico em relação ao direito. ${ }^{86}$ Sua interlocução com os teóricos da sociologia jurídica latinoamericana, nem sempre devidamente considerados no diálogo sociológico europeu, explicita bem sua postura contrária ao etnocentrismo intelectual. ${ }^{87}$

A capacidade de André-Jean Arnaud de transcender o eurocentrismo permitiu-lhe enfocar outros contextos de modo a apreender suas particularidades e, a partir daí, ultrapassando abordagens esquemáticas e caricatas, contribuir decisivamente para a sua efetiva apreensão. É nesse horizonte que se inscrevem suas análises acerca do Mercosul e do orçamento participativo, vistos como formas concretas de expressão da governança em nível regional e em territorial/ local, respectivamente. Trata-se de uma análise que procura estar atenta às especificidades dessas experiências, de modo a fugir às representações caricatas e depreciativas. ${ }^{88}$ Assim, seria possível afirmar que a perspectiva de Arnaud tem significativo potencial de elucidação relativamente à compreensão de experiências

85 Cf. CAPELLER, Wanda. André-Jean Arnaud: uma obra de transgressão, p. 18-20; CAPELLER, Wanda. Un regard différent: l'Amérique Latine, les juristes et la sociologie. Droit et Société, n. 22, p. 365-366, 1992.

86 Quanto ao Brasil, país em que houve um expressivo impacto da obra de André-Jean Arnaud, ver, por exemplo: FARIA, José Eduardo; CAMPILONGO, Celso Fernandes. A sociologia jurídica no Brasil. Porto Alegre: Fabris, 1991; SOUTO, Cláudio. Sociologia do direito: uma visão substantiva. 3. ed. Porto Alegre: Fabris, 2003. p. 111 e ss.

87 Cf. ARNAUD, André-Jean. O direito traído pela filosofia, p. 26.

88 Note-se que Arnaud analisa as experiências do Mercosul e do orçamento participativo de Porto Alegre, elevandoas ao estatuto de igualdade com as da União Europeia e do orçamento participativo na cidade de Toulouse. A respeito, ver: ARNAUD, André-Jean. La gouvernance. Un outil de participation, p. 158-162 e 228-258. 
sociais diversas das que ocorrem em seu contexto de origem porque assume um claro viés contra-hegemônico. Aliás, a respeito, cabe notar que já no início dos anos 80 Arnaud ressaltava criticamente o nexo entre desenvolvimento econômico e desenvolvimento da sociologia jurídica. ${ }^{89}$ Com isso, procurava explicitar a hegemonia de uma produção intelectual que, oriunda dos países desenvolvidos, tendia a se impor aos contextos subalternos, muitas vezes caricaturando-os. Ora, foi contra isso que mobilizou seu arsenal conceitual e agudo olhar crítico. ${ }^{90}$

\section{REFERÊNCIAS DAS FONTES CITADAS}

ALMEIDA, José Gabriel Assis de. Le cadre normatif du Mercosur. Droit et société. n. 59, p. 3953, 2005.

. Mercosul: manual de direito da integração. Rio de Janeiro: Lumen Juris, 2001.

AMARAL JÚNIOR, Alberto. Fragmentação e integração na América Latina. In: LAGOS, Ricardo (Coord.). A América Latina no mundo: desenvolvimento regional e governança internacional. São Paulo: Editora da Universidade de São Paulo, 2014, p. 51-61.

ARNAUD, André-Jean. Chercheur et décideur au coude à coude: un modèle de gouvernance. In: SOLINIS, Gérman (org.). Construire des gouvernances: entre citoyens, décideurs et scientifiques. Bruxelles: Peter Lang, 2005, p. 165-186.

Critique de la raison juridique 1. Où va la sociologie du droit? Paris: LGDJ, 1981.

Critique de la raison juridique 2. Gouvernants sans frontières. Entre mondialisation et post-mondialisation. Paris: LGDJ, 2003.

De la régulation par le droit à l'heure de la globalisation. Quelques observations critiques. Droit et Société, n. 35, p. 11-35, 1997.

Du jeu fini au jeu ouvert. Réflexions additionnelles sur le Droit post-moderne. Droit et Société, n. 17-18, p. 39-55, 1991.

Entre modernité et mondialisation. Leçons d'histoire de la philosophie du droit et de I'État. 2. ed. Paris: LGDJ, 2004.

Gouvernance (Bonne-). Gouvernance. In: (Dir.). Dictionnaire de la globalisation droit, science politique, sciences sociales. Paris: LGDJ, 2010. p. 269-270.

89 Cf. ARNAUD, André-Jean. Notes peut-être intempestives sur un thème qui m'est cher: où va la sociologie du droit? In: FERRARI, Vincenzo (Ed.). Developing sociology of law. A world-wide documentary enquiry. Milano: Giuffrè, 1990. p. 890-891; CAPELLER, Wanda. Un regard différent: l'Amérique latine, les juristes et la sociologie. p. 366.

90 Seu posicionamento mantém, portanto, forte afinidade com um movimento crítico de intelectuais latino-americanos acerca do caráter eurocêntrico das ciências sociais. À guisa de exemplo, ver as diversas análises disponíveis em: LANDER, Edgardo (Org.) La colonialidad del saber: eurocentrismo y ciencias sociales. Perspectivas latinoamericanas. 2. ed. Buenos Aires: Fundación CICCUS, 2016. 
Jean Carbonnier. Un juriste dans la cité. Paris: LGDJ, 2012.

Le droit trahi par la sociologie. Une pratique de l'histoire. Paris: LGDJ, 1998.

. Les origines doctrinales du code civil français. Paris: LGDJ, 1969.

Notes peut-être intempestives sur un thème qui m'est cher : où va la sociologie du droit? In: FERRARI, Vincenzo (Ed.). Developing sociology of law. A world-wide documentary enquiry. Milan, Giuffrè, 1990, p. 887-897.

O direito traído pela filosofia. Tradução de Wanda de Lemos Capeller e Luciano Oliveira. Porto Alegre: Sergio Antonio Fabris Editor, 1991.

Pour une pensée juridique européenne. Paris: PUF, 1991.

; CAPELLER, Wanda. A força do Estado em face da globalização. In: SOUTO, Cláudio; FALCÃO, Joaquim (Orgs.). Sociologia e direito: textos básicos para a disciplina de sociologia jurídica. 2. ed. São Paulo: Pioneira Thomson, 2002, p. 229-246.

; COTTERRELL, Roger. Comment penser le multiculturalisme en droit? L'Observateur des Nations Unies, v. 23, n. 2, p. 1-33, 2007.

; FARIÑAS DULCE, María José. Introduction à l'analyse sociologique des systèmes juridiques. Bruxelles: Bruylant, 1998.

; NOREAU, Pierre. The sociology of law in France: trends and paradigms. Journal of Law and Society. Vol. 25, n. 2, p. 257-283, p. 1998.

; SIMOULIN, Vincent. Gouvernance. In: ARNAUD, André-Jean (Dir.). Dictionnaire de la globalisation - droit, science politique, sciences sociales. Paris: LGDJ, 2010. p. 266-269.

BARON, Catherine. La gouvernance: débats autour d'un concept polysémique. Droit et Société, n. 54, p. 329-349, 2003.

BETTS, Alexander. Introduction: global migration governance. In: (Ed.). Global migration governance. Oxford: Oxford University Press, 2011, p. 1-33.

BOURDIEU, Pierre. Esprits d'État [Genèse et structure du champ bureaucratique]. Actes de la Recherche en Sciences Sociales, v. 96-97, p. 49-62, Mars. 1993.

Sur l'État. Cours au Collège de France 1989-1992. Paris: Seuil, 2012.

CAMPILONGO, Celso Fernandes. Interpretação do direito e movimentos sociais. Rio de Janeiro: Elsevier, 2012.

CAPELLER, Wanda. André-Jean Arnaud: uma obra de transgressão. In: ARNAUD, André-Jean. O direito traído pela filosofia. Tradução de Wanda de Lemos Capeller e Luciano Oliveira. Porto Alegre: Sergio Antonio Fabris Editor, 1991. p. 7-21. 
De que lugar falamos? Retomando um velho papo sobre o Direito e a Sociologia. Revista de Estudos Empíricos em Direito, v. 2, n. 2, p. 10-25, jan. 2015.

Relire Giddens. Entre sociologie et politique. Paris: LGDJ, 2011.

RSE et gouvernances solidaires au Brésil: entre nouvelles formes de socialité et nouveaux espaces publiques. Sociologies Pratiques, n. 18, p. 79-90, 2009.

. Un regard différent: I'Amérique Latine, les juristes et la sociologie. Droit et société, n. 22, p. 365-366, 1992.

; SIMOULIN, Vincent. La gouvernance: du programme de recherche à la transdisciplinarité (Présentation). Droit et Société, n. 54, p. 301-305, 2003.

CAPELLINI, Gustavo de Almeida; BONACIM, Carlos Alberto Grespan. Governança, governabilidade e coalizão política no processo orçamentário brasileiro. In: GONZÁLEZ, Felipe (Coord.); DAMIANI, Gerson; FERNÁNDEZ-ALBERTOS, José (Orgs.). Governança e democracia representativa. São Paulo: Editora da Universidade de São Paulo, 2017, p. 459-476.

CARBONNIER, Jean. Resenha crítica do livro "Essai d'analyse structurale du Code Civil français. La règle du jeu dans la paix bourgeoise." Archives de philosophie du droit. Vol. 20, p. 447-449, 1975.

CHEVALLIER, Jacques. La régulation juridique en question. Droit et Société, n. 49, p. 827-846, 2001.

L'État. Paris: Dalloz, 2011.

L'État post-moderne. 3. éd. Paris: LGDJ, 2008.

COMMAILLE, Jacques. À quoi nous sert le droit? Paris: Gallimard, 2015.

À quoi nous sert le droit pour comprendre sociologiquement les incertitudes des sociétés contemporaines? Sociologies [En ligne], Dossiers, Sociétés en mouvement, p. 1-12, 2016. Disponível em : http://sociologies.revues.org/5278. Consulta em: 07 mar. 2016.

Les enjeux politiques d'un régime de connaissance sur le droit. La sociologie du droit de Georges Gurvitch. Droit et société. n. 94, p. 547-563, 2016.

. L'ordre juridique comme désordre politique. Pouvoirs. n. 94, p. 75-86, 2000.

DAMIANI, Gerson; FERNÁNDEZ-ALBERTOS, José. Governança, poder e democracia representativa. In: GONZÁLEZ, Felipe (Coord.); DAMIANI, Gerson; FERNÁNDEZ-ALBERTOS, José (Orgs.). Governança e democracia representativa. São Paulo: Editora da Universidade de São Paulo, 2017, p. 25-32.

D'ARCY, François. Les perspectives politiques du Mercosur : comparaison avec I'Union européenne. Droit et société. n. 59, p. 19-35, 2005.

DELMAS-MARTY, Mireille. Le flou du droit. Paris: PUF, 2004. 
Les forces imaginantes du droit. Le relatif et l'universel. Paris: Seuil, 2004, . Les forces imaginantes du droit (II). Le pluralisme ordonné. Paris: Seuil, 2006. . Libertés et sûreté dans un monde dangereux. Paris : Seuil, 2010.

DELPEUCH, Thierry; DUMOULIN, Laurence; GALEMBERT, Claire de. Sociologie du droit et de la justice. Paris: Armand Colin, 2014.

DELPLANQUE, Marc. Gouvernance globale. In: ARNAUD, André-Jean (Dir.). Dictionnaire de la globalisation - droit, science politique, sciences sociales. Paris: LGDJ, 2010. p. 272-275.

DENORD, François; SCHWARTZ, Antoine. L'Europe sociale n'aura pas lieu. Paris : Raisons d'agir, 2009.

DUPUY, Claude; LEROUX, Isabelle; WALLET, Frédéric. Conflits, négociation et gouvernance territoriale. Droit et Société, n. 54, p. 377-396, 2003.

DURAN, Patrice. Gouvernance. Revue Politiques et Management Public, v. 16, n. 4, p. 3-4, 1998. EBERHARD, Christoph. Le droit au miroir des cultures. Pour une autre mondialisation. Paris: LGDJ, 2010.

O direito no mundo globalizado: em direção à "boa governança" através do diálogo intercultural. Direito, Estado e Sociedade, n. 33, p. 6-18, jul./dez. 2008.

FARIA, José Eduardo; CAMPILONGO, Celso Fernandes. A sociologia jurídica no Brasil. Porto Alegre: Sergio Antonio Fabris Editor, 1991.

FEDOZZI, Luciano Joel; MARTINS, André Luis Borges. Trajetória do orçamento participativo de Porto Alegre: representação e elitização política. Lua Nova, n. 95, p. 181-224, Aug. 2015.

GARCÍA VILLEGAS, Mauricio. Les pouvoirs du droit. Analyse comparée d'études sociopolitiques du droit. Paris: LGDJ, 2015.

; LEJEUNE, Aude. La sociologie du droit en France: de deux sociologies à la création d'un projet pluridisciplinaire. Revue interdisciplinaire d'études juridiques. V. 66, n. 1, p. 1-39, 2011.

GONZÁLEZ, Felipe. Por qué pensar la gobernanza? In: GONZÁLEZ, Felipe (Coord.); DAMIANI, Gerson; FERNÁNDEZ-ALBERTOS, José (Orgs.). Governança e democracia representativa. São Paulo: Editora da Universidade de São Paulo, 2017, p. 33-54.

HELD, David. Democracy and the Global Order: from the Modern State to Cosmopolitan Governance. Stanford: Stanford University Press, 1995.

Reframing Global Governance: Apocalypse Soon or Reform! New Political Economy, v. 11, n. 2, p. 157-176, jun. 2006. 
ISLA, Anne. Pour une économie institutionnelle et organisationnelle du droit: la gouvernance dans I'Union européenne. Droit et Société, n. 54, p. 353-373, 2003.

LANDER, Edgardo (Org.) La colonialidad del saber: eurocentrismo y ciencias sociales. Perspectivas latinoamericanas. 2. ed. Buenos Aires: Fundación CICCUS, 2016

LE ROY, Étienne. Gouverner la néo-modernité africaine? Cahiers d'anthropologie du droit - numéro spécial (Droit, gouvernance et développement durable). Paris: Karthala, 2005, p. 183-196.

LOCHAGIN, Gabriel Loretto. Lições latino-americanas para um mundo em crise: apontamentos para a governança internacional da dívida pública. In: LAGOS, Ricardo (Coord.). A América Latina no mundo: desenvolvimento regional e governança internacional. São Paulo: Editora da Universidade de São Paulo, 2014, p. 225-237.

MATTEI, Ugo; NADER, Laura. Plunder: when the rule of law is illegal. Oxford: Blackwell Publishing, 2008.

MULLER, Marion; LAUNAY-GAMA, Claire (Org.). Le pluralisme juridique et normatif, une voie pour refonder la gouvernance? Expériences africaines et latino-americaines de prise en compte de la diversité dans la régulation du droit officiel. Dossier proposé par l'IRG à l'occasion de la rencontre internationale "Pluralisme juridique dans les sociétés multiculturelles", Lima, 12-14 décembre 2011. Disponível em: http://www.institut-gouvernance.org/docs/dossierpluralisme-pro-fr.pdf $>$.

MACK, Adriana; DONZIS, Rubén. Las consecuencias de la globalización en el campo sóciojuridico. In: GONZÁLES, Manuela G.; LISTA, Carlos A. Sociología jurídica en Argentina: tendencias y perspectivas. Buenos Aires: Eudeba, 2011, p. 21-51.

OLIVEIRA, Alessandra Cavalcante. Aliança do Pacífico: desenvolvimento regional e governança internacional. In: LAGOS, Ricardo (Coord.). A América Latina no mundo: desenvolvimento regional e governança internacional. São Paulo: Editora da Universidade de São Paulo, 2014, p. 213-224.

ORTIZ, Laure. Préface. In: ARNAUD, André-Jean. La gouvernance. Un outil de participation. Paris: LGDJ, 2014.

OST, François. In memoriam - André-Jean Arnaud (1936-2015). Revue interdisciplinaire d'études juridiques. V. 76 (1), p. 1-3, 2016.

ROSANVALLON, Pierre. La légitimité démocratique: impartialité, réflexivité, proximité. Paris: Seuil, 2008.

Légitimité démocratique et gouvernance. Chroniques de la gouvernance 2009-2010. Paris: Éditions Charles Léopold Mayer, 2009, p. 13-18.

ROSENAU, James. Governança, Ordem e Transformação na Política Mundial. In: James Rosenau; Ernst-Otto Czempiel (Orgs.). Governança sem Governo: ordem e transformação na 
política mundial. Trad. Sérgio Bath. Brasília, DF: Editora UnB/Imprensa Oficial do Estado, 2000, p. 11-46.

SANTISO, Carlos. Parlements et démocratie budgétaire en Amérique Latine. In: BELLINA, Séverine; MAGRO, Hervé; VILLEMEUR, Violaine (Dir.). La gouvernance démocratique. Un nouveau paradigme pour le développement? Paris: Karthala, 2008, p. 223-236.

SCHWARTZ, Germano; COSTA, Renata Almeida da. André-Jean Arnaud e sua contribuição para a sociologia do direito brasileira. Revista brasileira de sociologia do direito. ABraSD, v. 3, n. 3, p. 114-127, set.-dez. 2016.

SIMOULIN, Vincent. La gouvernance et l'action publique: le succès d'une forme simmélienne. Droit et Société, n. 54, p. 307-326, 2003.

SOUTO, Cláudio; SOUTO, Solange. Sociologia do direito: uma visão substantiva. $3^{a}$ ed. Porto Alegre: Sergio Antonio Fabris Editor, 2003.

SUPIOT, Alain. L'Esprit de Philadelphie. La justice sociale face au marché total. Paris: Seuil, 2010. 2015. . La gouvernance par les nombres. Cours au Collège de France (2012-2014). Paris: Fayard,

VENTURA, Deisy. As assimetrias entre o Mercosul e a União Europeia: os desafios de uma associação inter-regional. São Paulo: Manole, 2003.

. A ordem jurídica do Mercosul. Porto Alegre: Livraria do Advogado, 1996.

La gouvernance démocratique et l'intégration économique. Regards croisés entre le Mercosur et l'Union européenne. Droit et société. n. 59, p. 93-103, 2005.

Mercosur. p. 352-354. In: ARNAUD, André-Jean (Dir.). Dictionnaire de la globalisation droit, science politique, sciences sociales. Paris: LGDJ, 2010. p. 269-270.

VILLAS BÔAS FILHO, Orlando. A governança em suas múltiplas formas de expressão: o delineamento conceitual de um fenômeno complexo. Revista Estudos Institucionais. V. 2, n.2, p. 670-706, 2016.

A juridicização e a judiciarização enfocadas a partir da "sociologia política do direito" de Jacques Commaille. Revista Brasileira de Sociologia do Direito, ABraSD, v. 2, n. 2, p. 56-75, jul.-dez. 2015.

A regulação jurídica para além de sua forma ocidental de expressão: uma abordagem a partir de Étienne Le Roy. Revista Direito \& Práxis, v. 6, n. 12, p. 159-195, 2015.

As transformações da regulação jurídica na sociedade contemporânea: a governança como paradigma (resenha de ARNAUD, André-Jean. La gouvernance. Un outil de participation. Paris: LGDJ, 2014). Revista Direito GV, v. 12, n. 1, p. 251-259, jan.-abr. 2016. 
Communication. In: ARNAUD, André-Jean (Dir.). Dictionnaire de la globalisation - droit, science politique, sciences sociales. Paris: LGDJ, 2010. p. 69-72.

Democracia: a polissemia de um conceito político fundamental. Revista da Faculdade de Direito da USP, v. 108, p. 651-696, jan.-dez. 2013.

Democracia: estado idílico da política? Revista Brasileira de Ciências Sociais, São Paulo, v. 25, n. 74, p. 183-186, out. 2010.

Différenciation fonctionnelle. In: ARNAUD, André-Jean (Dir.). Dictionnaire de la globalisation - droit, science politique, sciences sociales. Paris: LGDJ, 2010. p. 144-148.

. Juridicidade: uma crítica à monolatria jurídica como obstáculo epistemológico. Revista da Faculdade de Direito da USP, v. 109, p. 281-325, jan.-dez. 2014.

. O impacto da governança sobre a regulação jurídica contemporânea: uma abordagem a partir de André-Jean Arnaud. REDES - Revista eletrônica direito e sociedade, v. 4, n. 1. p. 145171, 2016.

WIHTOL DE WENDEN, Catherine. Le droit d'émigrer. Paris : CNRS Éditions, 2013.

. Faut-il ouvrir les frontières? Paris : Presses de Science Po, 2014.

XIFRA, Jordi. Qué es transparencia (si existe en relaciones públicas)? In: FARIAS, Luiz Alberto de; LOPES, Valéria de Siqueira Castro (Orgs.). Comunicação, governança e organizações. Porto Alegre: EDIPUCRS, 2016, p. 19-30.

XUE-BACQUET, Beinan; COLLETS, Gabriel. Gouvernance d'entreprise. In: ARNAUD, André-Jean (Dir.). Dictionnaire de la globalisation - droit, science politique, sciences sociales. Paris: LGDJ, 2010. p. 270-272.

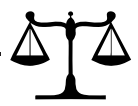

Recebido em: março/2017

Aprovado em: outubro/2017 